\title{
Late Cenozoic basin development of the eastern North Sea Basin
}

\author{
OLAF MICHELSEN
}

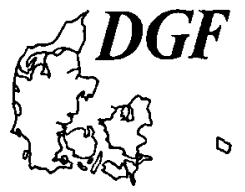

\begin{abstract}
Michelsen, O.: Late Cenozoic basin development of the eastern North Sea Basin. Bulletin of the Geological Society of Denmark, Vol. 43, pp. 9-21. Copenhagen, 1996-07-14. https://doi.org/10.37570/bgsd-1996-43-02
\end{abstract}

The Cenozoic succession in the Danish part of the North Sea Basin includes two significant breaks in sedimentation; 1) at the Eocene-Oligocene boundary and 2) at mid Miocene time.

The sediment transport direction was from the west during the Middle-Late Eocene and mainly from northeast and east in post Eocene times, and a change from a concordant seismic reflection pattern to a progradational pattern is seen. A clear change in lithology occurs at the Eocene-Oligocene boundary, from a finegrained clay-dominated deposit below the boundary to a clay with silt and mica above. Near shore marine and fluvial sediments of Early Oligocene to midMiocene age are known from the offshore and onshore areas, witnessing that the coastline migrated into the basin for the first time since the earliest Cretaceous. This change in sedimentation pattern was probably caused by the initial uplift of Scandinavia.

At mid Miocene time a significant environmental change occurred in the North Sea. A change from dark coloured to light coloured deposits indicates introduction of a well-oxygenated environment. A marked increase in rate of sedimentation (and subsidence) is evidenced by the approx. $1500 \mathrm{~m}$ thick sedimentary package in the central part of the basin. Late Middle Miocene starved sedimentation seen in the central North Sea may indicate a significant increase in subsidence rates.

The base of the Quaternary is a major erosional unconformity, mainly created by erosion caused by uplift of Scandinavia. $1000-1200 \mathrm{~m}$ of uplift is calculated for the eastern part of the North Sea Basin. With a post-Eocene subsidence of $2500 \mathrm{~m}$ in the central North Sea, the amplitude of the post-Eocene tectonic movements is approx. $3700 \mathrm{~m}$.

Olaf Michelsen, Department of Earth Sciences, University of Aarhus, DK-8000 Århus C, Denmark. 14th March 1996.

\section{Introduction}

During the Cenozoic time, the North Sea region constituted a large epicontinental basin, which was flanked by the positive areas of Scandinavia to the east and the British Isles to the west. The post-Danian Cenozoic deposits in the central part of the North Sea Basin reach thicknesses of more than $3000 \mathrm{~m}$, reflecting an almost continuous subsidence during most of the erathem. The Cenozoic succession in the Danish North Sea sector has not experienced major faulting. The depositional pattern is influenced mainly locally by 1) Palaeogene inversion tectonism, 2) syn-depositional halokinetic movements of the Zechstein evaporates and salt induced faulting and 3) very small fault displacements (Clausen \& Korstgård, 1993a, 1993b). Towards the east-northeast in the Danish sector, the deposits are truncated by Quaternary deposits, caused by late Cenozoic uplift and erosion (Doré, 1992; Jensen \& Michelsen, 1992).

The Cenozoic deposits in the Danish North Sea sector are documented by cuttings samples and some few conventional cores from deep wells and by seismic sections. The Cenozoic deposits onshore Denmark are documented in outcrops and cored shallow boreholes.

The onshore Cenozoic section is punctuated by a number of hiati, and the known total thickness of the post-Danian succession is approx. $700 \mathrm{~m}$. Most of the onshore strata are marine. Marginal Palaeogene sediments were probably deposited on the Fennoscandian Shield and along the Fennoscandian Border Zone, but have been removed as a result of the late Cenozoic 


\section{LOCATION MAP}

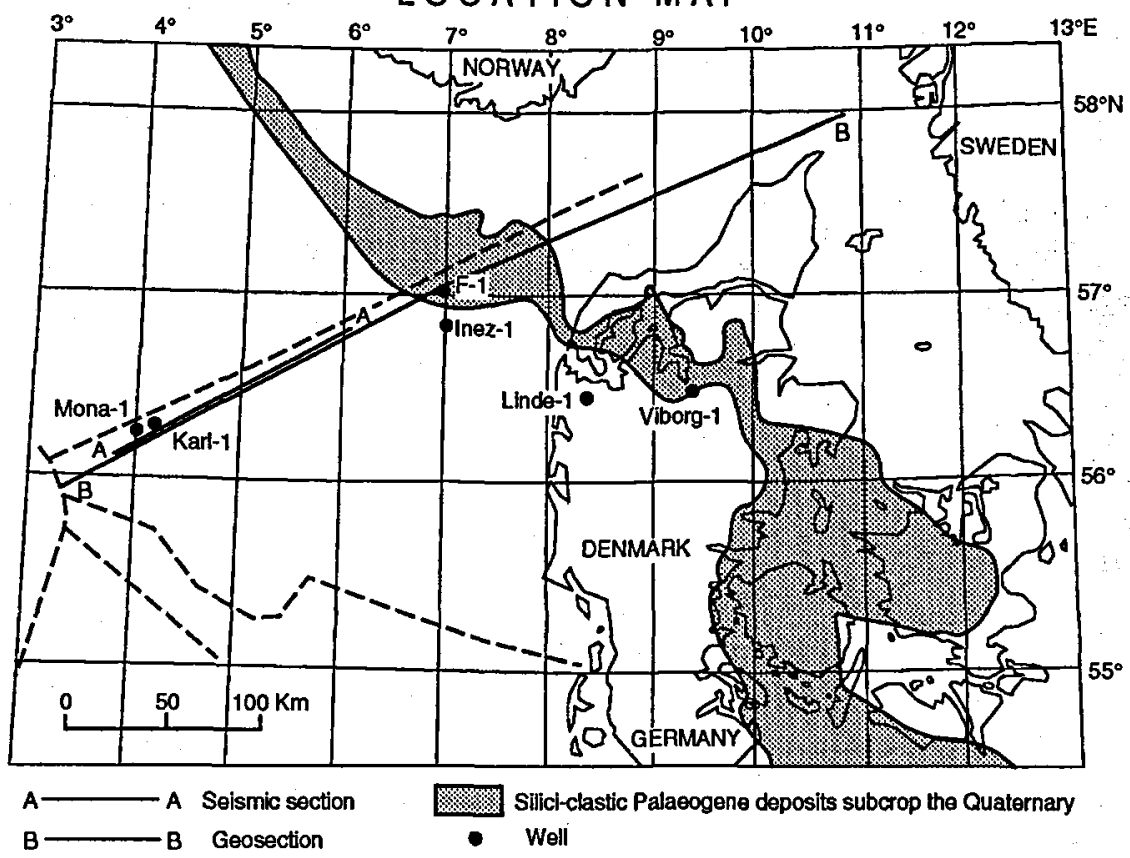

Fig. 1. Map of the Danish offshore og onshore areas, includes location of the wells and seismic sections referred to in this paper. The eastern extension of the Neogene deposits and the Palaeogene siliciclastic deposits is shown. regional uplift and subsequent erosion. Only during part of Late Oligocene and Miocene times, the coastline was situated in Denmark.

Clay- and marl-dominated marine sediments are known from the Upper Paleocene-Upper Oligocene (Christensen \& Ulleberg, 1973, 1974, Dinesen et al., 1978, Heilmann-Clausen et al., 1985, Heilmann-Clausen, 1989). The uppermost Oligocene-Pliocene deposits are characterized by silty marine clays intercalated by more coarse-grained sediments, deposited in shallow marine, lagoonal and floodplain environments (Larsen \& Dinesen, 1959, Rasmussen, 1961, Radwanski et al., 1975, Friis, 1978, Koch, 1989). Coarse-grained nearshore deposits were thus deposited in the Danish area for the first time since the earliest Cretaceous.

Clay and silty clay, deposited in a sublittoral to upper bathyal environment, constitute the major part of the Palaeogene and Neogene succession in the Danish North Sea (Michelsen et al., in press). The lithology of the Upper Paleocene succession resembles those described by Isaksen \& Tonstad (1989) from the southern part of the Norwegian sector. The lower Eocene comprises reddish and greenish clays, resembling those known from the Danish onshore Røsnæs Clay and Lillebælt Clay Formations (Heilmann-Clausen, 1989), whereas the overlying Eocene sediments may only be characterized as marine clay deposits. The Oligocene and Miocene sediments consist of clay with an upward increasing amount of silt and mica deposited in a sublittoral environment. A few wells in the northeastern part of the Danish sector have penetrated rather thick sand deposits, probably belonging to a near shore marine environment (Michelsen et al., in press, Michelsen \& Danielsen, in press). A basinward migration of the coastal environments is thus evidenced to have taken place earlier than known from the onshore data.

The present paper describes aspects of the late Cenozoic basin development in the eastern North Sea Basin, including the Danish onshore area (Fig. 1). The paper deals with the depositional development during the Oligocene to Pliocene Epochs, and controlling factors such as sea-level changes and subsidence/uplift will be discussed. The paper was compiled for a symposium at University of Aarhus in 1995, and mainly reviews earlier studies:

I) A sequence stratigraphic study of the Cenozoic sequences in the southeastern North Sea, including a biostratigraphic dating of the sequences (Michelsen et al., 1995, Michelsen et al., in press). A precise correlation between the North Sea sequences and the Danish onshore formations is demonstrated in

Fig. 2. Stratigraphic correlation between North Sea sequences and the Danish onshore lithostratigraphy, and an interpreted tentative sea-level curve (modified from Michelsen et al. (in press) and Michelsen (1994)). 


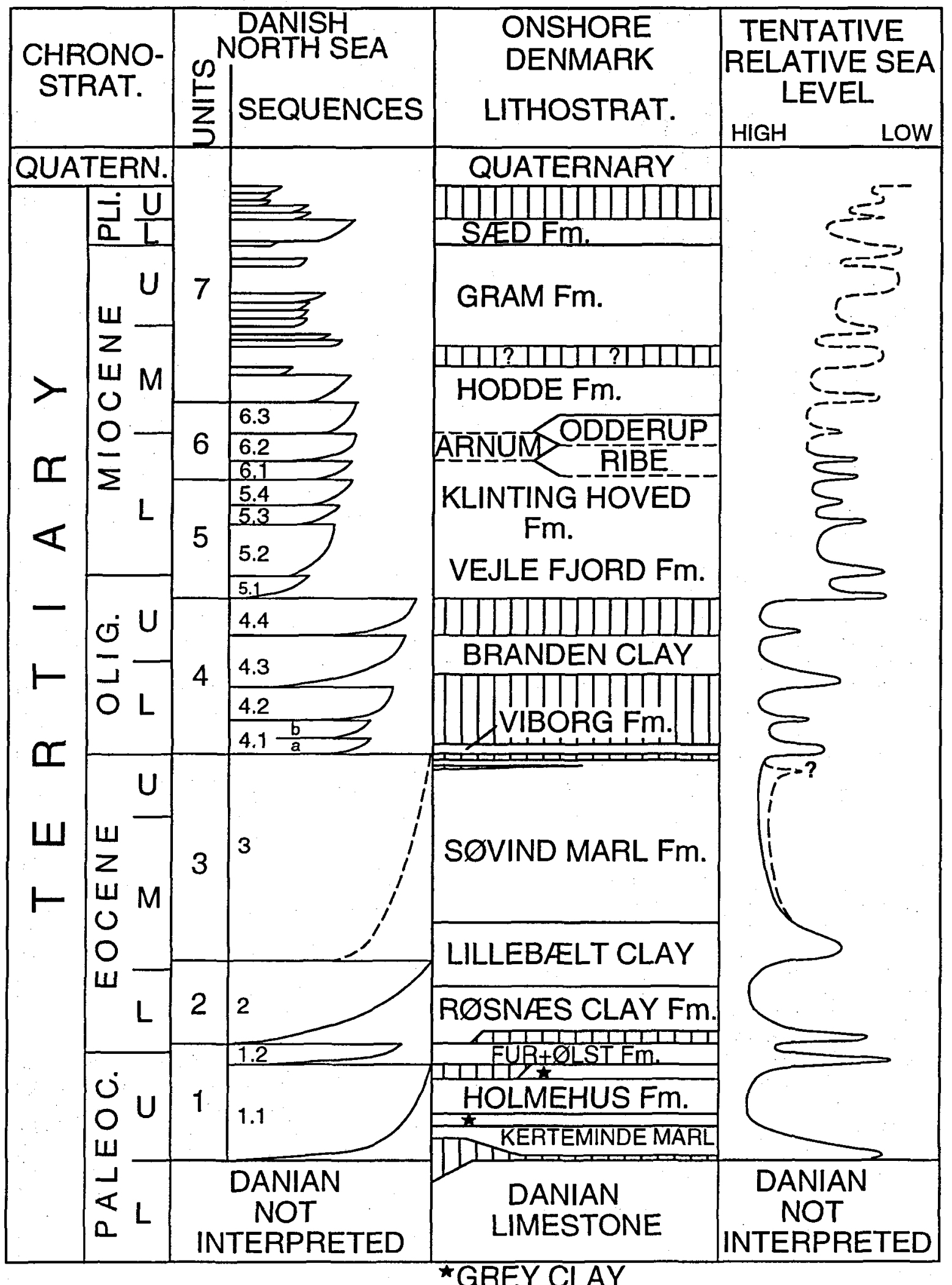




\section{DEPOCENTRES OF CENOZOIC SILICI-CLASTIC DEPOSITS}
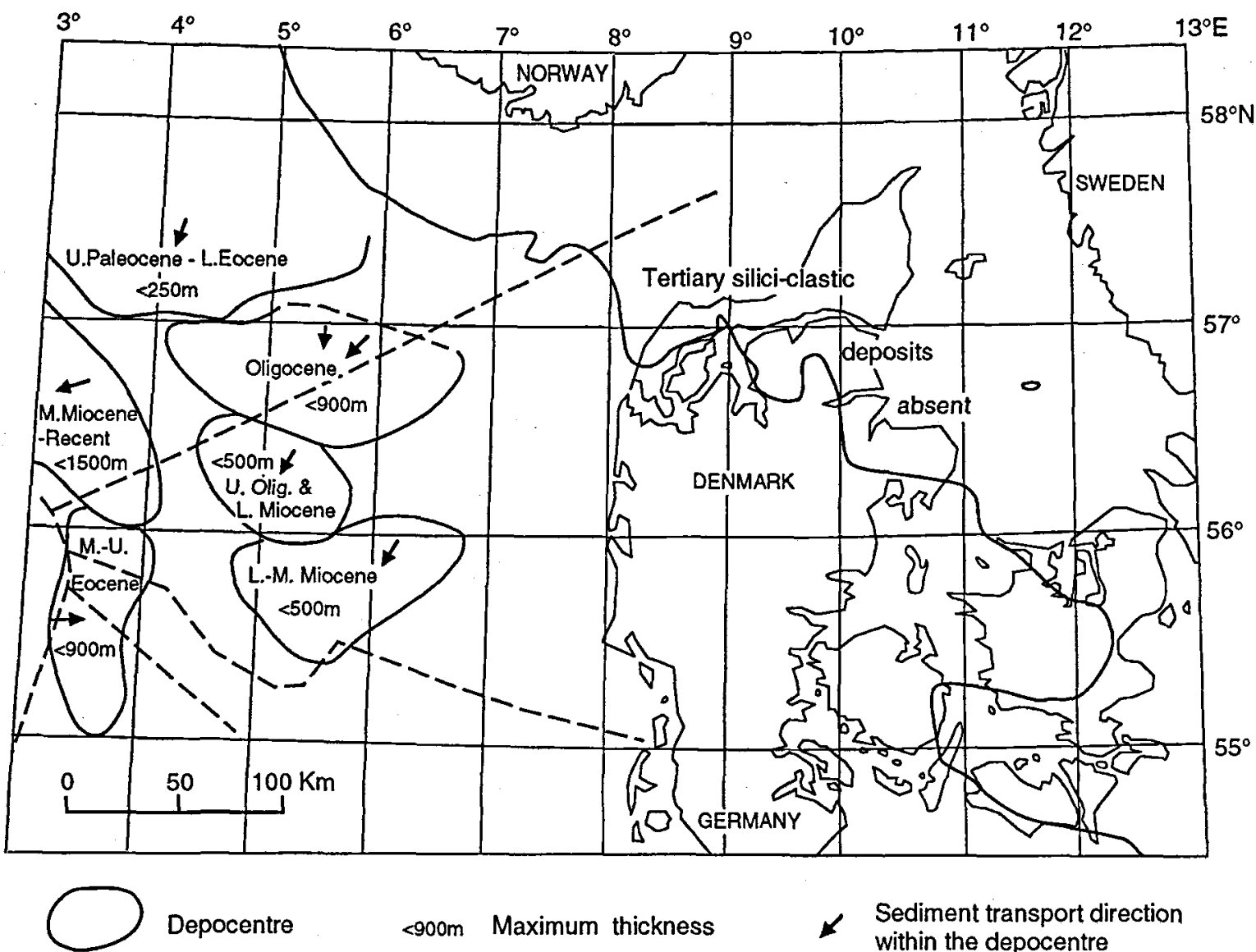

Depocentre

$<900 \mathrm{~m}$ Maximum thickness

Sediment transport direction within the depocentre

Fig. 3. Location of Cenozoic depocentres and the interpreted sediment transport directions (modified from Michelsen et al. (1995)). The eastern extension of the Palaeogene silici-clastic deposits is shown.

Michelsen (1994) and Michelsen et al. (in press). A few of the major sequence stratigraphic surfaces in the North Sea are time-equivalent with regional unconformities onshore Denmark (Fig. 2).

II) An analysis of the late Cenozoic regional uplift of the eastern margin of the basin, based on studies of over-pressured claystones by means of sonic trends (Jensen \& Michelsen 1992, Michelsen \& Nielsen, 1993), suggesting that the present delimitation of the silici-clastic Palaeogene-Neogene deposits (Fig. 3) is mainly caused by erosion due to the late Cenozoic uplift of the Scandinavian area.

The remaining part of this paper mainly reviews the sequence stratigraphic study and biostratigraphic dating presented in Michelsen et al. (1995) and Michelsen et al. (in press) and, therefore, further references to the two papers will not be given.

\section{Depositional development}

\section{Eocene-Oligocene transition}

The southeastern North Sea Basin was filled with sediments sourced from different directions during the Paleogene-Neogene. The dominant directions of sediment transport were mainly from the north during the Late Paleocene and Early Eocene, and from the west during the Middle-Late Eocene (Fig. 3). The Upper Paleocene to Lower Eocene section in the Danish North Sea sector comprises deep shelf deposits, which are approx. $100 \mathrm{~m}$ thick in the western part of the sector, and thins toward the east. These deposits represent the distal parts of sequences with the depocentres located further north in the North Sea (Fig. 3).

Approximately 900 m of Middle-Upper Eocene claydominated sediments are present in the westernmost part of the Danish North Sea sector, and thins to less than $100 \mathrm{~m}$ east of the Central Trough area. They pass 


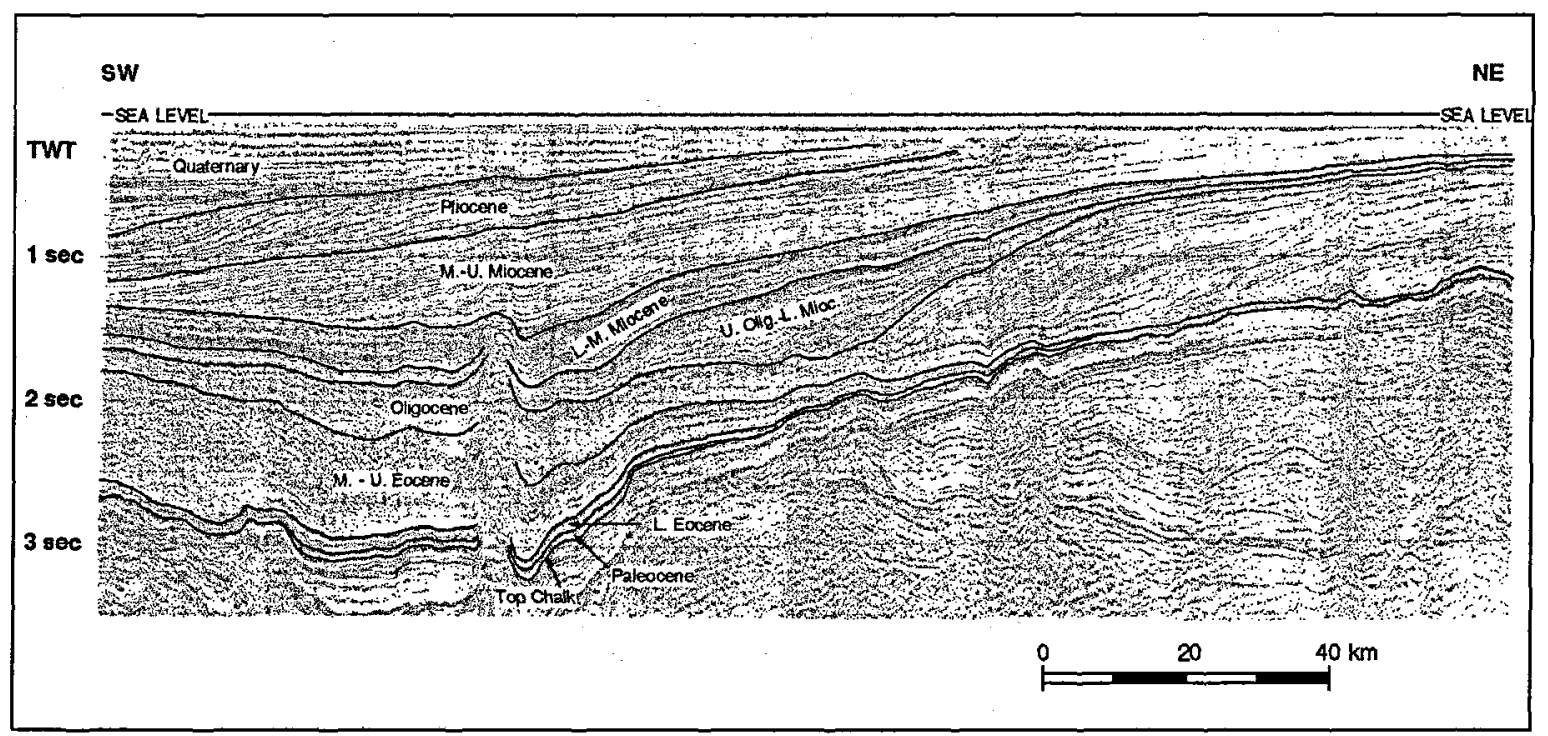

Fig. 4. Stratigraphic interpretation of the seismic section RTD 81-22 (modified from Michelsen et al. (in press)). Location: A-A in Figure 1. Notice: 1) the change from a concordant reflection pattern to a progradational pattern at the EoceneOligocene boundary, and 2) the aggradational pattern of the mid-Upper Miocene section. The base of the latter section is a pronounced downlap surface.

into the upper part of the onshore Lillebælt Clay Formation and the Søvind Marl Formation. A marked subsidence of the basin must have taken place to create the necessary space of accommodation, since the global sea level seems to fall slightly in this period (Haq et al., 1988). The thickness distribution suggests that the main subsidence occurred in the central and western parts of the basin.

At the transition to the Oligocene, a change to northern and northeastern directions of sediment transport took place (Fig. 3). The transport direction gradually changed to the northeast and east during the Miocene and Pliocene The composite depocentre of the Oligocene sequences $4.1-4.4$, with a maximum thickness of $900 \mathrm{~m}$, is located on top of the distal and condensed part of the pre-Oligocene sequences. The thickness drops to $200 \mathrm{~m}$ further to the west, on the top of the Eocene depocentre. The latest Oligocene to $\mathrm{mid}$ Miocene sequences 5.1-5.4 (500 m) and 6.1-6.3 (500 $\mathrm{m})$ were mainly deposited above the basinward slope of the Oligocene deposits (Fig. 3), filling in the basin and indicating a decrease in rates of new accommodation space created.

The base of the Oligocene deposits shows a clear change in lithology from a fine-grained clay-dominated deposit below the boundary to a clay with silt and mica above. Olive grey to brownish grey, silty clay dominates the lithology of the Oligocene, which also is characterized by a higher content of illite and kaolinite than in the underlying Eocene deposits. The Eocene-Oligocene boundary is generally indicated by a marked upward increase in gamma ray values, reflecting the illite- and kaolinite-dominated deposits rich in mica. A corresponding change from marl to silty and micaceous clay is observed in the onshore Søvind Marl Formation and Viborg Formation. Sorgenfrei (1949 and 1951) suggested that the change was caused by climatic changes or tectonic disturbances or that the final phase of filling in the North Sea Basin is indicated.

The Oligocene section is characterized by a prograding seismic reflection pattern, which is in marked contrast to the concordant reflection pattern of the underlying units (Fig. 4). The changes in the stratal pattern, in the lithology and in the sediment transport direction were probably controlled by the initial uplift of Scandinavia, causing a shift in source area. The uplift and the subsequent erosion is also indicated by the presence of redeposited microfossils in the Viborg Formation, derived from the Middle-Upper Eocene Søvind Marl, older Palaeogene deposits and Upper Cretaceous chalk (Christensen \& Ulleberg, 1973; Heilmann-Clausen, 1989).

\section{Oligocene to mid Miocene}

The Oligocene deposits (sequences 4.1(a,b)-4.4, see Figure 2) cover a large part of the Danish North Sea sector, with a composite depocentre in the NorwegianDanish Basin (Fig. 3). The four sequences are identified and mapped by means of seismic sections and logs. Sequence 4.1 has later been recognized in a few wells as a composite sequence, comprising sequence $4.1 \mathrm{a}$ 


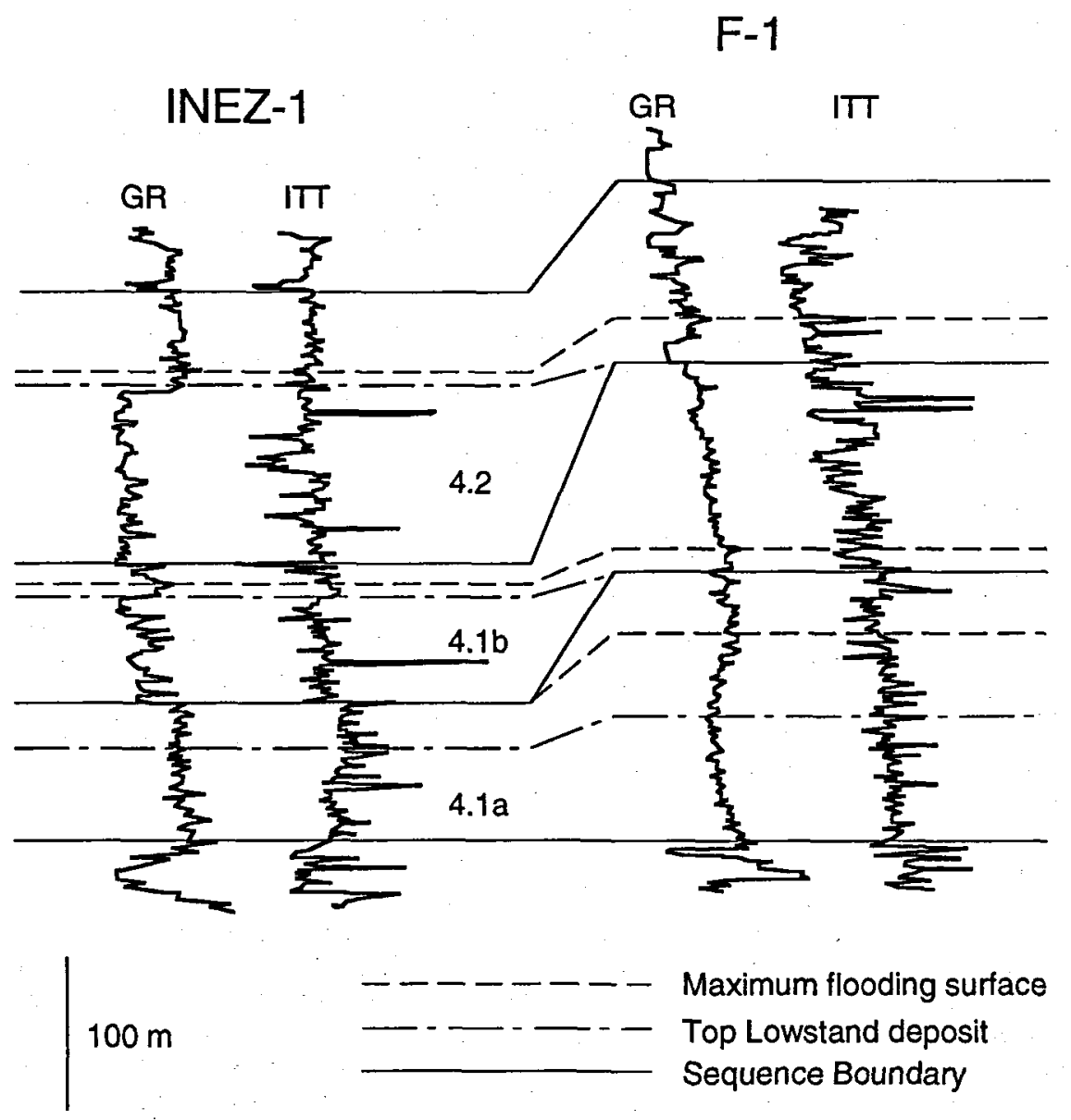

Fig. 5. Sequence stratigraphic interpretation of the earliest Oligocene deposits (sequence 4.1a, 4.1b and 4.2) in the F-1 and Inez-1 wells (for location see Figure 1). Lowstand deposits of sequences $4.1 \mathrm{~b}$ and 4.2 are marked by the blocky gamma ray patterns with low values in the Inez-1 well, reflecting coarse-grained marine quartz sand deposited in a shoreface environment. The well sections show an overall upward increasing grain-size trend of sequences $4.1 \mathrm{a}, \mathrm{b}$ and 4.2 , indicating a successive basinward migration of depositional facies.

and $4.1 \mathrm{~b}$ which have not been mapped separately (Michelsen \& Danielsen, in press). The depocentres of the four sequences are gradually displaced toward the centre of the basin. The sigmoidal to oblique progradational patterns of the sequences and the presence of toplaps at the top sequence 4.4 indicate an almost constant maximum rate in generation of accommodation space, signifying that the relative sea level repeatedly reached approximately the same maximum level during deposition of the four sequences.

Biostratigraphic data reveal that the lower part of sequence 4.1 (possibly 4.1 a) is time-equivalent with the onshore Viborg Formation, and sequence 4.3 partly is time-equivalent with the overlying Branden Clay (Fig. 2). Thus, most of sequence 4.1, all of sequence 4.2, and the lower part of sequence 4.3 fall within the hiatus between the Viborg Formation and the Branden Clay.
The Viborg Formation is a marine clay-dominated unit deposited "in a fairly stable environment under conditions of gradually decreasing current competence, brought about by a rising sea level" (Christensen \& Ulleberg, 1974). The basal glauconitic clay was probably produced during the transgression. A stable benthonic foraminiferal fauna characterizes the formation, but an increasing number of planktonic foraminifera occur approx. $15 \mathrm{~m}$ above the base of the formation in the Viborg-1 borehole. The formation is regarded as an outer shelf deposit (Christensen \& Ulleberg, 1974). The upward coarsening character of the formation may refer it to highstand deposits of the North Sea sequence 4.1a (or sequence 4.1b).

Thick lowstand deposits with sand are identified in sequences $4.1 \mathrm{~b}$ and 4.2 in the northeastern part of the Danish North Sea sector, as illustrated by the blocky gamma ray patterns with low values in the Inez-1 well 
(Fig. 5). The log patterns show a lower part with a blocky pattern of rather constantly low gamma ray values and an upper part with an upward coarsening trend in 4.1b. Constantly low values are seen in 4.2. Cuttings samples reveal coarse-grained marine quartz sand as the dominating lithology. These coarse-grained, marine sediments are interpreted as deposited during a relative sea-level fall, forcing a basinward migration of the shoreface environment (Michelsen \& Danielsen, in press). The coarse-grained lowstand deposits are located far west of the onshore location of the Viborg Formation, which may thus represent the corresponding highstand deposits. The onshore area may have been a sedimentary bypass area in periods characterized by a low relative sea level. However, since the sediment transport seems to have been from the north, coarse-grained lowstand deposits may have been deposited north of the Viborg location (Fig. 1), and successively removed by erosion caused by the uplift.

Well sections from the northeastern part of the Danish North Sea sector show an overall upward increasing grain-size trend of sequences $4.1 \mathrm{a}, \mathrm{b}$ and 4.2 (Fig. 5 ), indicating a successive basinward migration of the sedimentary facies and probably of the coastline. Timeequivalent shoreface deposits are not known from the Danish onshore area. The transition from sequence 4.2 to 4.3 is associated with a clear basinward shift in onlaps, indicating a considerable relative sea-level fall between deposition of these two sequences (Fig. 2). The hiatus between the onshore Viborg Formation and Branden Clay may have been created by erosion during this relative sea-level fall.

The transition from sequence 4.4 to sequence 5.1 is of latest Oligocene age, and the sequence boundary is marked by a pronounced basinward shift of onlaps at the lower boundary of sequence 5.1, indicating a major relative sea-level fall. Correlation between the North Sea sequences and the onshore formations also evidences a clear lowering of the relative sea level during Late Oligocene time. The onshore Branden Clay partly correlates with North Sea sequence 4.3, and the onshore Vejle Fjord Formation (incl. the Klinting Hoved Formation, according to Friis (1989)) correlates with sequences 5.1 to 6.1 (Fig. 2). The Branden Clay is interpreted as an open marine shelf deposit and the glauconitic lower part of the formation includes an acme of planktonic foraminifera (Ulleberg, 1987), which most likely reflects the period of maximum flooding of the sea during deposition of sequence 4.3. The overlying part of the Branden Clay is characterized by an upward increasing content of silt (HeilmannClausen, 1989), and may be regarded as a highstand deposit. The younger Vejle Fjord Formation was deposited in a coastal to lagoonal environment (Larsen and Dinesen, 1959; Radwanski et al., 1975), showing a basinward migration of the coastal environment. The hiatus between the Vejle Fjord Formation and the underlying Branden Clay corresponds to the time of deposition of sequence 4.4 and was probably created by erosion during the following major relative sea-level fall. A subsequent basinward (westward) migration of the coastline is evidenced by the onshore data, indicating that the accommodation space for sedimentation was significantly reduced during the latest Oligocene time. The Vejle Fjord Formation includes fresh, unstable weathering products of crystalline rocks. The source was the old metamorphic rocks of Fennoscandia, indicating a continued uplift and erosion in the marginal part of the basin. In the onshore well, Linde-1, sequence 5.1 is barren of foraminifera, whereas 5.2 includes redeposited Paleocene and Eocene foraminifera (Laursen, 1995), indicating continued erosion of Palaeogene deposits.

The pronounced basinward (westward) shift of onlaps at the lower boundary of sequence 5.1 was followed by an overall landward (eastward) migration of the basal onlaps during deposition of sequences 5.2, 5.3 and 5.4 (Fig. 2). The deposits consist of dark greenish grey to dark brown clay, containing an upward increasing amount of organic matter. The sediments of the onshore Vejle Fjord Formation were deposited during repeated transgressive phases (Friis, 1989). The upper part, the Vejle Fjord Sand, shows an upward coarsening trend and is interpreted to reflect landward migration of barrier sands across lagoonal deposits. A recent study of the formation from outcrops and wells by Nielsen (1995) shows that sequence 5.4 represents a renewed basinward (westward) shift of onlaps. A landward migration followed by a basinward migration of the coastline during deposition of the latest Oligocene to Lower Miocene Vejle Fjord Formation is suggested by Nielsen (1995). The further basinward migration of the sedimentary facies is documented by the presence of the younger fluvial sediments (the Ribe Formation) in western Jylland, as demonstrated by Rasmussen (1961).

The Early-Middle Miocene deposits, which are included into sequences $6.1-6.3$, represent the final phase of progradational deposition, which started at the Eocene-Oligocene boundary in the southeastern North Sea (Fig. 4). Dark greenish grey to dark brown clays dominate the deposits; and contain an upward increasing amount of organic matter. The three sequences are approximately time-equivalent with the onshore deposits, included in the marine Arnum and Hodde (partly) Formations and the fluvial Ribe and Odderup Formations (Fig. 2). The intercalated marine and fluvial deposits of the onshore formations reflect repeated changes in the relative sea level, which may correspond to the relative sea-level changes interpreted from the North Sea sequences. The biostratigraphic data of the North Sea sequences and of the onshore formations do not allow a precise correlation. However, the boundary between sequence 5.4 and 6.1 is suggested to be positioned within the upper part of the Vejle Fjord Formation, and the upper boundary of sequence 6.3 within the Hodde Formation. The composite depocentre of sequences 6.1-6.3 is located basinward of the 


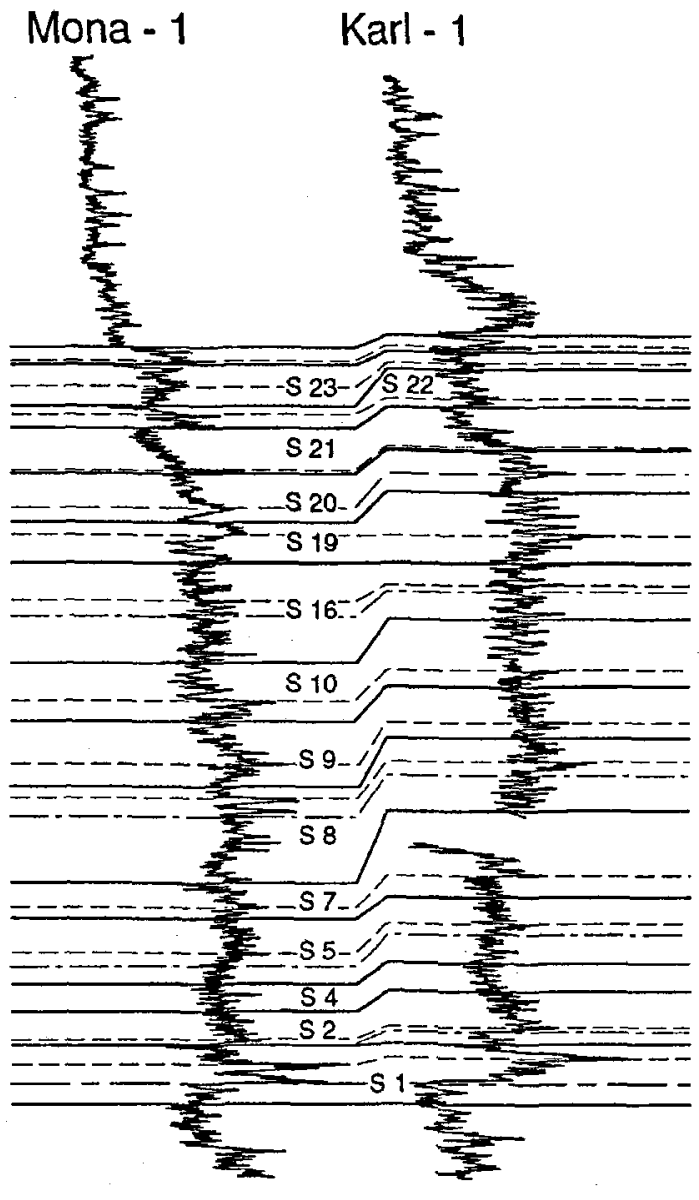

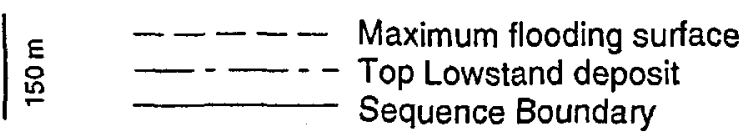

Fig. 6. Sequence stratigraphic interpretation of the post-mid Miocene deposits in the Karl-1 and Mona-1 wells (for location see Figure 1). Notice the prominent gamma ray peak(s) in sequence $\mathbf{S 1}$, which probably correlates with the upper part of the onshore Hodde Formation and the lower glauconitic part of the Gram Formation, and represents a period with starved sedimentation in the central North Sea Basin. The overall lithology shows an upward coarsening trend, which may reflect the increasing sediment supply during the Late Miocene and Pliocene. Modified from Sørensen \& Michelsen (in press).

underlying sequence depocentre (Fig. 3). The dominance of shallow marine and non-marine deposits in the uppermost Oligocene to mid Miocene onshore formations indicates that the overall relative sea level remained low after the late Oligocene fall (Fig. 2). The presence of the onshore fluvial deposits may reflects that the accommodation space was further slightly reduced during the Early-mid Miocene times, probably caused by continued uplift. The overall equal appearance of the relative sea-level curve, interpreted for the eastern North Sea (Fig. 2), and the global sea-level curve by Haq et al. (1988) suggest that the rate of subsidence further west in the basin largely kept pace with the rate of sediment influx.

\section{Mid Miocene to Recent}

The mid Miocene to Recent deposits in the North Sea represent a significant change in the basin development. The depocentre is found in the central North Sea, and the direction of sediment transport was from the east (Fig. 3). More than $1500 \mathrm{~m}$ of sediments were deposited from mid Miocene time to Recent (approx. $13 \mathrm{Ma}$ ) in the central part of the North Sea, which equals the underlying approx. $1500 \mathrm{~m}$ of Upper Paleocene to mid Miocene sediments deposited during a $48 \mathrm{Ma}$ long period. The marked increase in subsidence rates is described in the following chapter.

The mid to Upper Miocene section is characterized by a conform aggradational stratal configuration (Fig. 2 ), reflecting rapid creation of new accommodation space. The seismic reflections usually downlap to the west, characterizing the lower boundary as a seismic downlap surface (Fig. 4). The post-mid Miocene interval has been subdivided into 31 sequences (Sørensen \& Michelsen, in press), and the lowermost part is characterized by two gamma ray peaks with high values. The interval including the two peaks is included into the lowermost sequence (S1), which is approx. $70 \mathrm{~m}$ thick in the Karl-1 well (Fig. 6). The sequence spans more than one foraminiferal NSB zone, corresponding to approx. $2.5 \mathrm{Ma}$, and thus represents a period with a very low sedimentation rate, compared to the overlying Upper Miocene-Pliocene interval.

A thin interval below the gamma ray peaks consists of black clay with a high content of organic matter, and glauconitic clay is found in the interval with the two gamma ray peaks. The section including the thin organic rich interval and the gamma ray peaks correlate, according to the biostratigraphy, with the upper dark-coloured part of the Hodde Formation and the lowermost glauconitic part of the Gram Formation. This section probably reflects starved sedimentation associated with maximum flooding conditions.

The two gamma ray peaks are clearly linked with a significant change of the environmental conditions. The deposits change from almost black to olive grey or light olive grey in colour. The light colours and a low content of organic matter continue up through the Upper Miocene and Pliocene sections, and the content of sand and silt increases upward. The biostratigraphic data indicates a higher rate of sedimentation for the section above the gamma ray peaks. The foraminifera faunas from the central North Sea furthermore indicate a gradual shallowing of the North Sea Basin from the 
lower to the upper part of the sublittoral zone during the period mid Miocene to Recent.

Data from the onshore Danish formations suggest that the relative sea level probably increased most rapidly in the beginning of this period. The planktic foraminifera increase in numbers upwards through the Hodde Formation and they are fairly common in the overlying Gram Formation (Kristoffersen, 1972). This indicates an increase in oceanic influence. The benthic faunas, on the other hand, suggest a shallower environment for the Gram Formation.

A change to a progradational pattern occurred in earliest Pliocene (Figs 2 and 4), possibly due to an increased rate of sediment influx compared to the rate of new accommodation space created.

\section{Regional structural development of the North Sea Basin}

\section{Subsidence of the basin}

The isopach maps published by Sorgenfrei (1969) and Ziegler (1982) demonstrate the geometry of the Cenozoic sedimentary package in the North Sea, which represents a continuous filling of the basin, without erosional events in the central part of the basin.

Deposition of more than $3000 \mathrm{~m}$ of marine sediments in the northern part of the Danish Central Trough during the post-Danian Cenozoic times indicates a high subsidence rate. Using the time scale published by Haq et al. (1988) and disregarding the degree of compaction, a minimum average rate of $49 \mathrm{~m}$ pr. Ma can be calculated for the northern part of the Danish Central Trough area.

The post-Eocene succession, which was deposited during the uplift episode of the basin margin, is up to $2500 \mathrm{~m}$ thick in the northern part of the Danish Central Trough area. The global sea-level curve of Haq et al. (1988) shows an overall falling tendency since Eocene times. The accommodation space established for accumulation of the thick succession of marine deposits in the central North Sea Basin have mainly been caused by basin subsidence. A subsidence rate of $69.5 \mathrm{~m}$ pr. Ma may be calculated. This may indicate increasing subsidence rates during the later part of the Cenozoic.

The mid Paleocene to mid Miocene succession shows a consistent lateral thickness which slightly increases in the Central Trough area (Fig. 4). Therefore, major differential subsidences may not be interpreted within the area covered by the cross section. The North Sea Basin was gradually filled in during the Oligocene to mid Miocene time. The latest Oligocene to mid Miocene depocentres are mainly located on the basinward slope of the Oligocene depocentre (Fig. 3), indicating only a minor increase in the available accommodation space. The approx. $1000 \mathrm{~m}$ thick Oligocene to mid
Miocene section corresponds to an average subsidence rate of $43.5 \mathrm{~m}$ pr. Ma.

The mid Miocene to Recent depocentre found in the central part of the North Sea Basin represents a second phase of filling in the basin. The $1500 \mathrm{~m}$ thick mid Miocene to Recent section corresponds to a subsidence rate of $115 \mathrm{~m}$ pr. Ma. This value is probably a minimum figure, since the calculation represents the southern and thinning part of the depocentre and since the eastern delimitation of the depocentre is controlled by erosion.

The basin thus seems to have experienced a rather even rate of subsidence during the pre-mid Miocene part of the Cenozoic, whereas a significant increase in subsidence rates obviously occurred at mid Miocene time. The starved sedimentation during the late Middle Miocene, indicated by the lithology and thickness of the interval with the before-mentioned gamma ray peaks and by the biostratigraphic data, support this interpretation. It is, therefore, suggested that major differential subsidence of the North Sea Basin and the most significant increase in subsidence rates took place at mid Miocene time.

\section{Uplift of the eastern part of the basin}

The sequence stratigraphic study has clearly revealed that the Oligocene to Pliocene deposits are truncated toward the north and east. The base of the Quaternary is a major erosional unconformity in the Kattegat, northern Jylland and the Skagerrak areas (Fig. 7). The Quaternary subcrop map shows that the Quaternary overlies Neogene deposits in the central part of the North Sea, Palaeogene in the eastern part, the Upper Cretaceous to Danian limestone in north Jylland and Kattegat, and Jurassic and Triassic at the eastern margin of the basin. The present extension of the Mesozoic and Cenozoic deposits towards the east and northeast is mainly controlled by erosion.

The erosion was primarily caused by the late Cenozoic uplift of the Scandinavian region, and secondarily by glacial processes. The late Cenozoic uplift of the Scandinavian region has been discussed in detail by different authors in the last few years, but was earlier suggested by Spjeldnæs (1975). A number of scientists have tried to evaluate the magnitude of elevation by using different methods, e.g. vitrinite reflections and sonic velocities of the Mesozoic succession (e.g. Doré, 1992; Jensen \& Schmidt, 1992 and 1993; Jensen \& Michelsen, 1992; Michelsen \& Nielsen, 1993). The investigations are based on the concepts of maturation and compaction controlled by depth of burial. The degree of compaction reached at a certain depth of burial will not change, when the formation is uplifted to a more shallow position.

The magnitude of uplift has been calculated in a number of Danish wells (Jensen \& Michelsen, 1992; Michelsen \& Nielsen, 1993). The sonic velocity trend 


\section{PRE-QUATERNARY SUBCROP}

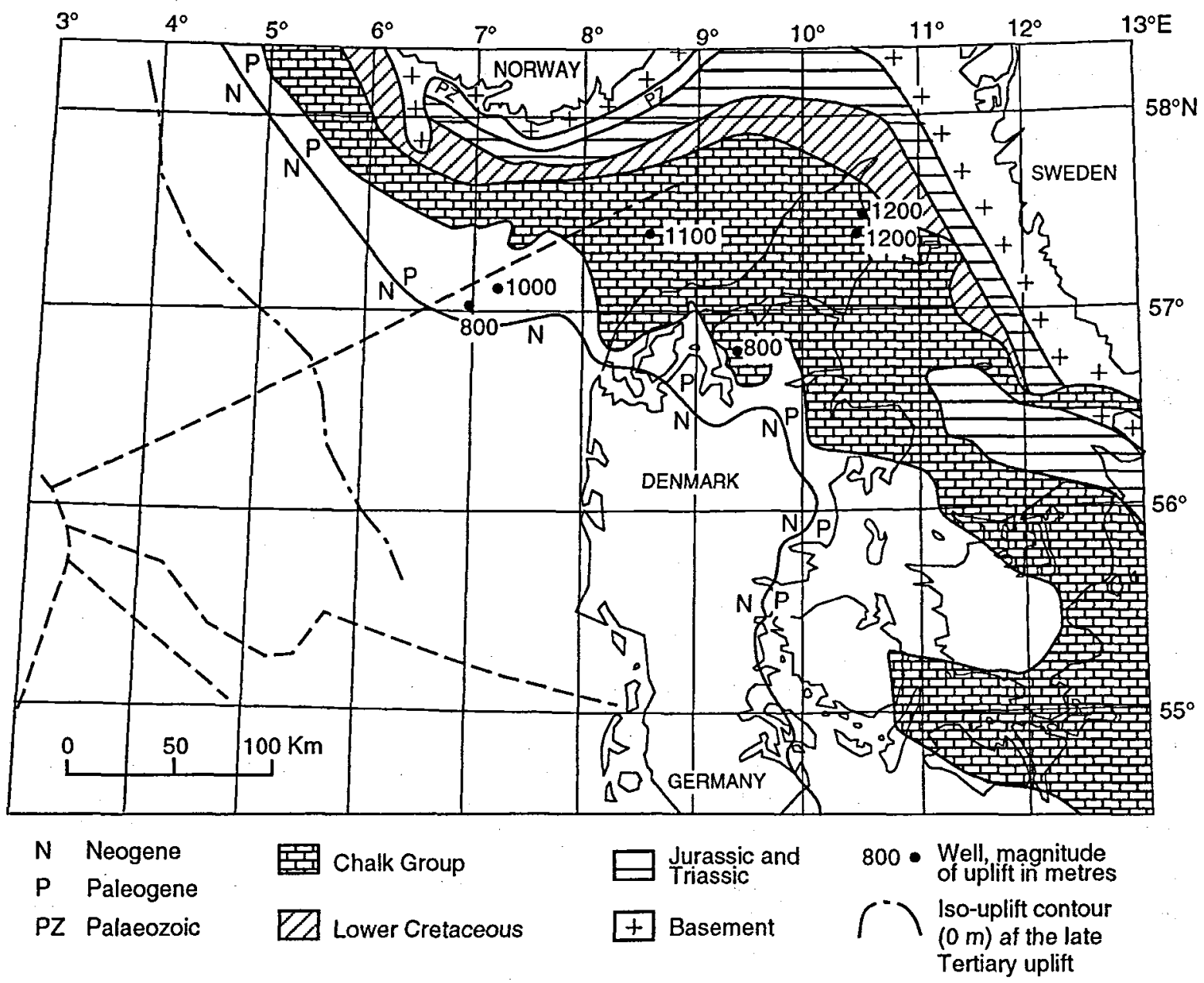

Fig. 7. Pre-Quaternary subcrop map. The interpreted magnitude of the late Cenozoic uplift is indicated at selected well locations, and the 0 iso-uplift contour (hinge line) is shown (modified from Jensen \& Michelsen (1992)).

of Lower Jurassic claystones is used, assuming that the trend reflects the degree of compaction and diagenesis. As these processes are irreversible in claystone, the results of the subsidence experienced are preserved in the sedimentary rock. An uplift gradient is interpreted from wells located at a section from the centre of the North Sea Basin to the eastern margin (north Jylland and Kattegat): $1200 \mathrm{~m}$ in northernmost Jylland, $800 \mathrm{~m}$ in central Jylland, and $1000 \mathrm{~m}$ in the North Sea northwest of Jylland (Figs 7 and 8).

The iso-uplift contours presented by Jensen \& Michelsen (1992) conforms to the Norwegian and Swedish coastlines. It is worth noticing that the hingeline is located far out in the North Sea, east of the Central Trough (the $0 \mathrm{~m}$ iso-uplift contour in Figure 7). The hinge-line has probably moved from a more easterly position during the time of uplift. The stratigraphy of the Cenozoic deposits, reviewed above, indicate that the uplift started no later than at the transition from the Eocene to the Oligocene. The changes in stratal configuration, sediment transport direction and lithology at the Eocene-Oligocene boundary show the introduction of a new source area located at the northeastern margin of the basin, in the Scandinavian region. The presence of Middle-Upper Eocene microfossils in the lowermost Oligocene Viborg Formation may also indicate the initial uplift and subsequent erosion. 


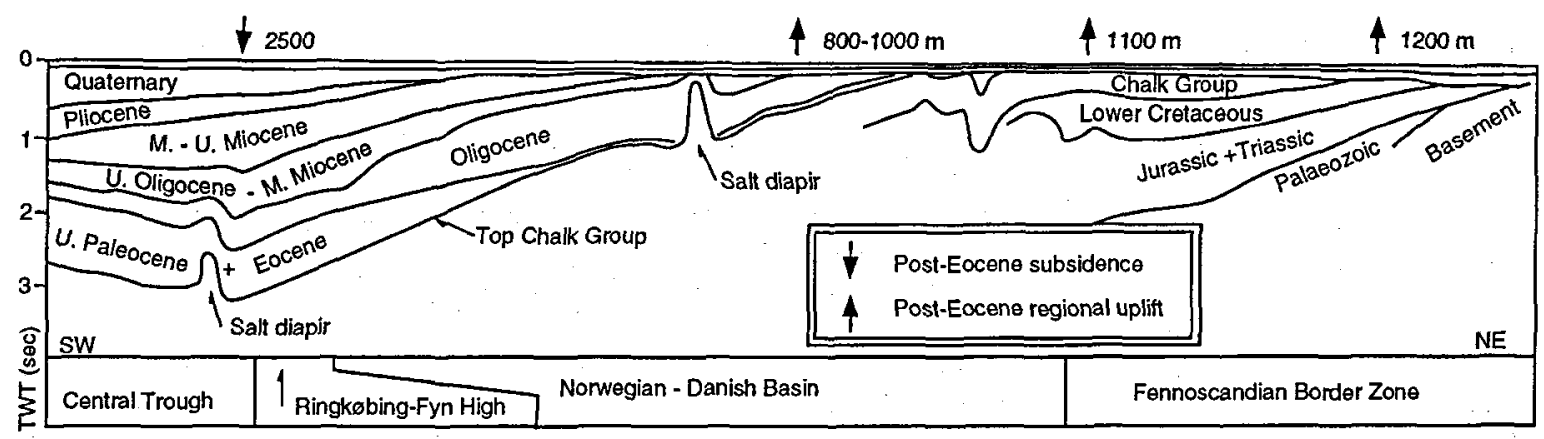

Fig. 8. Geosection (B-B in Figure 1) based on interpretation of seismic sections and wells (simplified and modified from Jensen \& Michelsen (1992)). The interpreted magnitude of the post-Eocene uplift of marginal part of the North Sea Basin and the corresponding subsidence of the central part of the basin are indicated. Notice that the major part of the subsidence (approx. $1500 \mathrm{~m}$ ) took place in post-mid Miocene time.

\section{Conclusions}

The sequence stratigraphic studies of the Cenozoic succession in the North Sea have revealed two significant breaks in sedimentation; at the Eocene-Oligocene boundary and at mid Miocene time. According to biostratigraphic data these two breaks are located in onshore sections between the Søvind Marl Formation and Viborg Formation and within the Hodde Formation, respectively.

At the Eocene-Oligocene boundary changes in the stratal pattern, in the lithology and in the sediment transport direction indicate a shift to a new source area, which was located to the east and northeast of the basin, probably in Scandinavia. This conclusion is supported by earlier interpretation of the uppermost Oligocene to Lower Miocene Vejle Fjord Formation (Larsen \& Dinesen, 1959).

The progradational pattern which characterizes the Oligocene to mid Miocene deposits in the North Sea and the basinward migration of coastal near and fluvial deposits indicate that the North Sea Basin was gradually filled in with sediments during this period.

The Mid Miocene to Recent period represents the second phase of filling in the basin. At mid Miocene time a significant environmental change occurred. The change from dark coloured deposits to light coloured indicates introduction of a well-oxygenated environment. Starved sedimentation in the Middle Miocene and the Upper Miocene aggradational pattern indicate that the rate of relative sea-level rise increased relatively to the rate of sediment influx. This relationship was reversed during the Pliocene. Biostratigraphic data indicates a high rate of sedimentation and a gradual shallowing of the North Sea Basin during the Late Miocene to Recent period.

The subsidence rates of the central North Sea Basin seem to have changed at mid Miocene time, when the average rate increased from approx. $45 \mathrm{~m}$ pr. Ma to approx. $115 \mathrm{~m}$ pr. Ma.
The base of the Quaternary appears as a major erosional unconformity. The present extension of the Mesozoic and Cenozoic deposits towards the east and northeast is mainly controlled by erosion caused by uplift of Scandinavia. $1200 \mathrm{~m}$ uplift is calculated for the northernmost Jylland and approximately $1000 \mathrm{~m}$ for eastern North Sea. The hinge line is located east of the Central Trough area. The significant break in depositional conditions indicates that the uplift started at the Eocene-Oligocene boundary. A post-Eocene subsidence of the central North Sea Basin of $2500 \mathrm{~m}$ is suggested. The amplitude of the post-Eocene tectonic movements, which affected the North Sea Basin, is of a considerable dimensions, creating a large monocline, nearly without fault activities. Measured from the northernmost Jylland to the central North Sea the amplitude is approx. $3700 \mathrm{~m}$.

\section{Dansk sammendrag}

Den kænozoiske lagserie på dansk landområde og i Nordsøen indeholder to markante ændringer i sedimentationsforholdene: På overgangen mellem Eocæn og Oligocæn samt i Mellem Miocæn.

Basis Oligocæn i Nordsøen er markeret ved en ændring fra konkordante til prograderende seismiske reflektionsmønstre (Fig. 4). Litologisk ses ændringen som en overgang fra de eocæne ler- og mergelaflejringer under grænsen til de oligocæne siltholdige leraflejringer med glimmer over grænsen. Seismisk kortlægning af aflejringerne indikerer en sedimenttransport fra vest $i$ Mellem og Sen Eocæn og fra nord-nordøst $i$ Oligocæn (Fig. 3).

De oligocæne til midt miocæne aflejringer i Nordsøen har en overordnet prograderende tendens med sedimenttilførsel fra nord $\varnothing$ st, og den successive flytning af depocentrene mod den centrale del af bassinet indikerer en opfyldning af bassinet i denne periode (Fig. 3 
og 4). Forekomsten af nedre oligocæne kystnære aflejringer $\mathrm{i}$ den nord $\varnothing$ stlige del af dansk Nords $\varnothing$ område (Fig. 5), øvre oligocæne til nedre miocæne kystnære aflejringer (Vejle Fjord Formationen) samt nedre-mellem miocæne fluviatile aflejringer (Ribe og Odderup Formationerne) på landområdet viser, at kystzone gradvis migrerede ud i bassinet $\mathrm{i}$ denne periode.

Denne udvikling som startede på Eocæn-Oligocæn overgangen sættes i forbindelse med hævningen af det skandinaviske område. Hævningen er beregnet til ca. $1200 \mathrm{~m}$ i Nordjylland og til ca. $1000 \mathrm{~m}$ i Nordsøen nordvest for Jylland. Hængselslinien er tolket til at ligge umiddelbart $\varnothing$ st for Central Truget (Fig. 7).

Mellem Miocæn i Nordsøen er karakteriseret ved en seismisk downlap-flade, den "midt miocæne inkonformitet" (Fig. 4). Boringsdata viser forekomsten af et kondenseret interval ved denne flade. Det seismiske reflektionsmønster for lagserien over downlap-fladen udviser en aggraderende karakter. Det er foreslået, at indsynkningshastigheden i midt til Sen Miocæn tid har oversteget hastigheden for tilførsel af sediment.

Den post-midt miocæne lagserie er $1500 \mathrm{~m}$ tyk i den centrale del af Nordsøen, og en betydelig indsynkningshastighed må antages at dominere i denne periode. Lægges her til $1000 \mathrm{~m}$ for de oligocæne til midt miocæne aflejringer, udgør den post-Eocæne lagserie $i$ alt $2500 \mathrm{~m}$ (Fig. 8). Under forudsætning af at det globale havniveau siden Eocæn har være faldende, må indsynkningen centralt i Nordsøen have være mindst $2500 \mathrm{~m}$. Sammenholdt med den beregnede hævning af bassinets marginale dele må resultatet af de posteocæne tektoniske bevægelser være en niveauændring langs en linie fra de centrale til de marginale dele af bassinet på mindst $3700 \mathrm{~m}$.

\section{References}

Christensen, L. \& Ulleberg, K. 1973: Sedimentology and micropaiaeontology of the Middle Oligocene Viborg Formation. Denmark. Bulletin of the Geological Society of Denmark 22, 283-305.

Christensen, L. \& Ulleberg, K. 1974: Sediments and foraminifera of the Middle Oligocene Viborg Formation, Denmark. Bulletin of the Geological Society of Denmark 23, 109-117.

Clausen, O. R. \& Korstgård, J. A. 1993a: Tertiary tectonic evolution along the Arne-Elin Trend in the Danish Central Trough. Terra Nova, 5, 233-243.

Clausen, O. R. \& Korstgård, J. A. 1993b: Small-scale faulting as an indicator of deformation mechanism in the Tertiary sediments of the northern Danish Central Trough. Journal of Structural Geology, 15 (11), 1343-1357.

Dinesen, A., Michelsen, O. \& Lieberkind, K. 1978: A survey of the Paleocene and Eocene deposits of Jylland and Fyn. Danmarks Geologiske Undersøgelse B 1, 15 pp.

Doré, A. G. 1992: The base Tertiary surface of southern Norway and the northern North Sea. Norsk Geologisk Tidsskrift 72, 259-265.
Friis, H. 1978: Heavy-mineral variability in Miocene marine sediments in Denmark: a combined effect of weathering and reworking. Sedimentary Geology 21, 169-188.

Friis, H. 1989: Neogene aflejringer. In Nielsen, O. B. \& Sandersen P. (eds) Danmarks Geologi - fra øvre kridt til i dag.Geologisk lnstitut, Aarhus University 1, 22 pp.

Haq, B. U., Hardenbol, J. \& Vail, P. R. 1988: Mesozoic and Cenozoic chronostratigraphy and cycles of sea-level change. In Wilgus, C. K., Posamentier, H., Roos C. A., and Kendall, C. G. St. C. (eds) Sea-Level Changes - An Integrated Approach: Society of Economic Paleontologists and Mineralogists, Special Publication, 42, 71-109.

Heilmann-Clausen, C. 1989: Paleogene aflejringer over Danske kalken. In Nielsen, O. B. \& Sandersen P. (eds) Danmarks Geologi - fra øvre kridt til i dag. Geologisk Institut. Aarhus University $1.44 \mathrm{pp}$.

Heilmann-Clausen, C., Nielsen, O. B. \& Gersner, F. 1985: Lithostratigraphy and depositional environments in the Upper Paleocene and Eocene of Denmark. Bulletin of the Geological Society of Denmark 33, 287-323.

Isaksen D. \& Tonstad, K. (eds) 1989: A revised Cretaceous and Tertiary lithostratigraphic nomenclature for the Norwegian North Sea. NPD-Bulletin 5, $59 \mathrm{pp}$.

Jensen, L. N. \& Michelsen, O. 1992: Tertiær hævning og erosion i Skagerrak, Nordjylland og Kattegat. Dansk geologisk Forening, Årskrift for 1990-91, 159-168.

Jensen, L. N. \& Schmidt, B. J. 1992: Late Tertiary uplift and erosion in the Skagerrak area: magnitude and consequences. Norsk geologisk Tidskrift, 72, 275-279.

Jensen, L. N. \& Schmidt, B. J. 1993: Neogene uplift and erosion offshore south Norway: magnitude and consequences for hydrocarbon exploration in the Farsund Basin. In: Spencer, A. M. (Ed.), Generation, Accumulation and Production of Europe's Hydrocarbons III. Special Publication of the European Association of Petroleum Geoscientists, 3, 79-88. Springer-Verlag, Berlin.

Koch, B. E. 1989: Geology of the Søby-Fasterholt area. Danmarks Geologiske Unders $\varnothing$ gelse, Ser. A, 22, 171 and $121 \mathrm{pp}$.

Kristoffersen, F. N. 1972: Foraminiferzonering i det jyske Miocæn: Dansk Geologisk Forening, Årsskrift for 1971, 79-85.

Larsen, G. \& Dinesen, A. 1959: Vejle Fjord Formationen ved Brejning. Danmarks Geologiske Undersøgelse, II Række, 82, 114 pp.

Laursen, G. V. 1995: Foraminiferal biostratigraphy of Cenozoic sections in five wells from the Danish area. EFP-92 Projekt: Tertiær bassinudvikling i Central Truget med særlig vægt på mulige reservoir forekomster. Rep. No. 20, University of Aarhus (unpubl. report).

Michelsen, O., 1994: Stratigraphic correlation of the Danish onshore and offshore Tertiary successions based on sequence stratigraphy. Bulletin of the Geological Society of Denmark, 41, 145-161.

Michelsen, O. \& Nielsen, L. H., 1993: Structural development of the Fennoscandian Border Zone, offshore Denmark. Marine and Petroleum Geology, 10, 124-134.

Michelsen, O. \& Danielsen. M. (in press): Sequence and systems tract interpretation of the epicontinental Oligocene deposits in the Danish North Sea. In: Geology of siliciclastic shelf seas. Geological Society, Special Publications.

Michelsen, O., Danielsen, M., Heilmann-Clausen, C., Jordt, H., Laursen, G. V. \& Thomsen, E., 1995: Occurrence of major sequence stratigraphic boundaries in relation to 
basin development in Cenozoic deposits of the southeastern North Sea. - In. Steel, R. J, Felt, V. L., Johannessen, E. P. \& Mathieu, C. (eds), Sequence stratigraphy on the Northwest European Margin. NPF Special Publication 5, 415-427, Elsevier, Amsterdam.

Michelsen, O., Thomsen, E., Danielsen, M., HeilmannClausen, C.\& Jordt, H., Laursen, G V. (in press): Cenozoic sequence stratigraphy in the eastern North Sea. - In de Graciansky, P.Ch., Jacquin, T. \& Vail, P. R. (eds) Mesozoic-Cenozoic Sequence Stratigraphy of Western European Basins, 2. Society of Economic Paleontologists and Mineralogists (SEPM).

Nielsen, K. S. 1995: Sekvensstratigrafisk analyse og tolkning af oligocæne og miocæne aflejringer $i$ den danske del af Nordsøen og på dansk onshore-område. M: Sc. Thesis, University of Aarhus, $134 \mathrm{pp}$.

Radwanski, A., Friis, H. \& Larsen, G. 1975: The Miocene

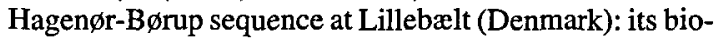
genic structures and depositional environment. Bulletin of the Geological Society of Denmark, 24, 229-260.

Rasmussen, L. B. 1961: De miocæne formationer i Danmark. Danmarks Geologiske Unders $ø$ gelse, IV Række, 4 (5), $45 \mathrm{pp}$.

Sorgenfrei, T. 1949: Nyere undersøgelser af Fyns undergrund. Meddelser fra Dansk Geologisk Forening, 11, 490493.

Sorgenfrei, T. 1951: Oversigt over prækvartærets topografi, stratigrafi og tektonik i området Fyn-Sydsjælland-LollandFalster-Møn. Meddelser fra Dansk Geologisk Forening, $12,166-171$.

Sorgenfrei, T. 1969: Geological perspectives in the North Sea area. Bulletin of the Geological Society of Denmark, 19, 160-196.

Spjeldnæs, N. 1975: Palaeogeography and facies distribution in the Tertiary of Denmark and surrounding areas. Norges geologiske Undersøgelse, 316, 289-311.

Sørensen, J. C. \& Michelsen, O. (in press): Upper Cenozoic sequences in the southeastern North Sea Basin. Bull. geol. Soc. Denmark, 42.

Ulleberg, K. 1987: Foraminiferal zonation of the Danish Oligocene sediments. Bulletin of the Geological Society of Denmark, 36, 191-202.

Ziegler, P. A. 1982: Geological atlas of western and central Europe. Elsevier Scientific Publishing Company, Amsterdam. $130 \mathrm{pp}$. 